\title{
Straw Men of Union Leadership
}

\author{
Clyde W. Summers $\dagger$
}

Labor and the American Community. By Derek C. Bok and John T. Dunlop. New York: Simon and Schuster, 1968. Pp. 542. \$12.50 (clothbound), \$3.95 (paperback).

Two leading scholars of labor relations-one a labor lawyer and one a labor economist-have canvassed here the large issues concerning labor unions which trouble and divide the American community. They demonstrate dramatically in the first chapter that although a large majority of people approve of unions in principle and support the right of workers to join unions, an equally large majority are also highly critical of what unions do. Majorities of varying sizes and compositions believe that many union leaders are corrupt and autocratic, that unions reduce productivity and cause unnecessary strikes and inflation, that union support of political candidates distorts our political processes, and that unions have not been responsive to present social needs.

The thesis of this book is that much of this criticism and public distrust of unions is unjustified, and the reason distrust is so prevalent, the authors assert, is because "unions are among the least understood of our social institutions." 1 Understanding is lacking not only in the general public but even more in the "intellectual critic" of the labor movement, "writers of a liberal or left persuasion" who "doubtless speak for a large segment of the liberal intellectual community." The authors set for themselves the task of explaining unions to the American people-both to the general public whose fear of union power leads to antiunionism and to the "liberal intellectuals" whose ideological belief in unions leads them to expect too much. ${ }^{3}$

+ Garver Professor of Law, Yale University.

1. D. BOK \& J. DunLop, LABOR AND the Asifrican Cosmintry 456 (1963) [hercinafter cited to page number only]. This is certainly not for lack of public discussion, published materials, detailed inquiries or scholarly studies, as a cursory glance at the authors' four hundred footnotes quickly reveals. That social institutions have been more extensively studied or are better understood in the authors' view are not indiated.

2. P. 30. See also, e.g., pp. 34, 89, 135, 384, 459, 472, 477. Among those named are C. Wright Mills, Sidney Lens, B.J. Widdick, A.H. Raskin, Danicl Bell, and the magazines Progressive, Commonweal, The Nation, and The New Republic.

3. The authors apparently view the task of educating the liberal intellectuals as the nost difficult, for they say, "Interestingly enough, in contrast with opinions on most other subjects, views about unions often seem to stray furthest from the facts the higher one moves up the scale of income and education." (P. 45\%). This is a disturbing view from the authors, who at the time of the book's publication were, respectircly, the Dean of the Law School and Dean of the Faculty of Arts and Sciences of Harvard University. 
The authors' treatment of unions is plainly sympathetic. Although union shortcomings are acknowledged, they are minimized or viewed from a perspective which makes them seem less large. For example, corrupt and dictatorial practices by some union leaders are admitted, but these leaders are described as constituting "only a tiny fraction of all union officials," 4 even though they include national officers of the Teamsters, Bakery Workers, Mine Workers, East Coast Longshoremen, Carpenters, Operating Engineers and other large and powerful unions. The number of convictions of union officers for embezzlement is described as small compared with the number of convictions of bank officials. Racial discrimination has been practiced by some unions, but, the authors explain, this has always been contrary to AFL policy; in 1961, the AFL-GIO convention adopted a "comprehensive resolution urging equal treatment of minorities," 5 but could not compel compliance for fear of widespread secession. To defend unions generally against charges of racial discrimination, the authors present statistical data to show that non-white workers have fared better in industries with high unionization than in industries with low unionization; ${ }^{0}$ and to defend the building trades unions in particular, the authors marshal data purporting to show that the penetration of Negroes into higher skilled jobs is greater in construction than in automobile and aerospace where the union has vocally opposed discrimination. ${ }^{7}$ From this they conclude that union discrimination cannot adequately explain the problem and that "more pervasive factors of social discrimination must be the primary factors at work."

The treatment of union leaders is even more sympathetic. They are overworked, undertrained and plagued by a pervasive shortage of capable staff and chronically tight budgets. The union political process diverts their energies, disrupts their continuity in office and makes

\section{P. 69. \\ 5. P. 121 . \\ 6. P. 126 .}

7. $\mathrm{Pp}$. 127-28. The comparison is based on percentage figures drawn from two separate studies. The construction industry figures were compiled by the IEOC and the auto-aerospace figures were compiled in a private survey. There is no indication that the same categories, methods of collection or calculations were used. Nor is there any mention of the significantly different role of the unions in controlling access to jobs in the construction and in the auto-acrospace industries. The Department of Labor, in developing the Philadelphia Plan, found that in Philadelphia exclusionary practices of unions had resulted in the following minority membership in six skilled craft unions in the Philadelphia area: Iron Workers, $1.4 \%$; Steamfitters, $65 \%$; Sheetmetal Workers, 1\%; Electricians, $1.76 \%$; Elevator Construction Workers, $54 \%$; and Plumbers, $51 \%$. At the same time there were qualified minority workers available for each craft who were not being employed in the craft. CCH Employment Practices Guide \$ 7155.56 (1969).

8. P. 129. 
them subservient to pressures from the membership. A recurrent theme of the book is that "liberal intellectuals" have unfairly blamed union leaders for faults of the labor movement which have their source in the union members. Union leaders might work harder to erase racial discrimination were it not for the prejudices of their members; ${ }^{0}$ union leaders have opposed restrictive work practices but union members have refused to follow; ${ }^{10}$ elected officers find it difficult to resist demands for inflationary wage increases when unions are required by law to follow democratic procedures; ${ }^{11}$ and the disinterest and hostility of union members help to explain the limited efforts of local union leaders to combat poverty, racial discrimination and urban squalor..$^{12}$

This sympathetic approach often fails to bring understanding because it is too intent on persuading, and it often fails to persuade because it tries to prove too much. However, it does serve the valuable purpose of emphasizing the complexity of the institutional structures and problems involved. In each of the problem areas, the authors elaborate variant forms the problem takes and identify multiple forces and values which work and weigh against each other. Singleness of blame or simplicity of solution is made unthinkable, and this is certainly the beginning of understanding.

The authors have attempted at the same time to be comprehensive in scope, and this is the beginning of the book's undoing. More than a dozen large problem areas, ranging from internal union democracy through collective bargaining in the public sector to the role of unions in urban problems, are discussed in less than five hundred pages. Such comprehensiveness, combined with insistence on the complexity of the problems, leads to a cursory canvassing of multiple factors with little evaluation of their relative importance or their interrelationships. ${ }^{13}$ This blurs critical issues and causes illuminating insights to be buried by banal observations. In addition, the studied effort to appear objective and to weigh all considerations often leads to a bland "on the one hand ... and on the other hand" recitation of arguments with an unconvinc-

9. P. 135.

10. P, 262.

11. P. 293.

12. P. 461 .

13. The scope of inclusion and exclusion is sometimes puzling. For example, in discussing the effect of unions on productivity, many forms of restrictions, from call-in pay and seniority to rejection of labor-saving devices and limitations on daily prosluction. are described. However, the impact on productivity of skilled craft unions with their rigid limitations on assignment of work, along with the jurisdictional friction this creates, is not mentioned. At the same time, valuable space is used to describe how under certain circumstances, requiring an employer to hire more labor than he needs may cause him to increase production and lower prices-an exceptional, if not purely theoretical case. See p. 263. 
ing "on balance" conclusion. It is regrettable, and puzzling, that authors with such richness of information and breadth of experience should believe it possible to discuss meaningfully so many complex problems in so little space.

More than space, however, is lacking. In defending unions and union leaders, the authors often attack straw men instead of coming to grips with real issues. For example, when purporting to confront directly the question whether unions can or should be more democratic in the sense of having more adequate democratic procedures, discussion is focused on the two-party system. Arguments are directed toward the unworkability of the two-party system in unions, with emphasis on some of the socially irresponsible policies of the International Typo. graphical Union which has had such a system. The relevant issue, however, is not the two-party system, for it is obvious that most unions will continue for the foreseeable future to be one-party bureaucracies. The critical and difficult question is how to protect democratic rights and build democratic processes into the one-party structure. The rights to criticize, to form opposition groups and to have access to channels of communication need special forms of protection; referenda on dues increases and ratification votes on collective agreements may be important checks on leaders who are difficult to dislodge; union elections which serve primarily to measure the level of membership dissatisfaction may require special structuring; and local autonomy may serve to prevent the bureaucracy from becoming monolithic. The authors never confront squarely what can be done, either by unions or by government, to provide meaningful democratic procedures within the one-party political process.

Other difficult problems are glossed over or wholly ignored. In defending unions against those who fear union political power, finan* cial contributions amounting to 10 or 20 per cent of the Democratic party receipts are described as "not overpowering,"14 and campaign activities which affect "no more than 5 per cent" of the vote are described as "not necessarily ... decisive." 15 The influence of the building trades unions in naming the Solicitor of Labor is suggested,10 but no mention is made of his crucial role in determining how firmly to enforce against these and other unions the financial reporting,

\footnotetext{
14. P. 414.

15. P. 417 .

16. P. 406. This relationship raises questions as to what weight and interpretation to place on statistics cited by the authors earlier (p. 66) showing only a small number of proceedings brought by the Department of Labor to invalidate union clections for viola. tions of Landrum-Grifin.
} 
trusteeship, and election provisions of Landrum-Griffin. On a broader level, the political compulsion on the Department of Labor to be responsible to "labor's reasonable demands" is described, ${ }^{17}$ but there is no recognition that such subservience of government departments to special interest groups raises serious problems for our political system. ${ }^{18}$ In defending a union's compelling an individual employee to contribute to political causes with which he disagrees, the authors dismiss the argument that the union thereby infringes on his personal freedom as one which would "appeal more to a judge than to a worker in the factory." 19 But several chapters later they recount, without comment, the practice of the St. Louis Pipe Fitters requiring a two dollar daily "donation" into the political fund from those who seek jobs through the union hiring hall. ${ }^{20}$ The possibility of protecting individual political rights without destroying union political effectiveness is never explored; the device suggested by the Supreme Court and successfully used in England-of segregating union political funds from general funds and allowing members to contract out of making contributions to the political fund-is not even mentioned. ${ }^{21}$

On most issues the ultimate thrust of the authors' defense of unions is one of mitigation, a plea to a lesser offense than some critics have charged. Unions are not "a major cause of inefficiency" and have less impact on efficiency than protective tariffs or import quotas; unions do enforce undesirable restrictive work practices, but they do so to protect the income and job security of their members."2 Unions are not "a major cause of inflation;" they force up prices "somewhat in certain industries," but they are "only a minor factor in inflation." Un Unions are not "the most powerful political interest group in the country" and have not been "particularly successful in electing . . . favored candidates," 24 but their political power has not been "negligible" and

17. P. 408 .

18. The fact that other groups have similar infuence over other agencies does not negate the presence of a serious problem, but rather raises it to a level of systemic proportions and increases the importance of recognizing and analyzing its manifestation here.

19. P. 101

20. P. 404 .

21. See Brotherhood of Railway Clerks v. Allen, 373 U.S. 113 (1963). The Supreme Court, in holding that employees could not be required by a union shop clause to contribute to union political expenditures, suggested that as a practical solution the mcm. bers' dues could be reduced in the proportion that the union budget was devoted to political activities; the unions could voluntarily adopt a plan like that legally imposed in England. The English statute is not only cited and discussed in the opinion, 375 U.S. at 123 , but is set out in full in an Appendix to the opinion. 373 U.S. at 124-29.

22. P. 457 .

23. Id.

24. Id. 
"must have contributed something to the success of the Democratic party" since 1933. ${ }^{25}$ Unions have failed to eliminate discrimination, have hardly been involved in urban problems, and have done little in the war on poverty, but they have done as much as their members wanted. ${ }^{28}$

To the charge that unions are undemocratic, the authors' plea is a combined denial and demurrer; unions are generally democratic in the sense of being responsive to their members, and to the extent that they are not democratic this is not an offense but a virtue. The authors equate democracy with all methods by which members exert pressure on their leaders and urge that the primary weakness of unions is that they are too responsive to their members.

The authors dutifully recite the fundamental values in maintaining democratic procedures, ${ }^{27}$ but a few pages later assail critics who "assume that union democracy is simply an end in itself"28 and then conclude that "[i]n certain respects . . . concern over these matters has been carried to excess." 29 The dangers of majority rule are recounted, the costs of democratic procedures are elaborated, and the tendency of union members to vote their narrow self-interest is repeatedly emphasized. "A candid appraisal," the authors declare, "compels the conclusion that the rank and file has contributed to most of the widely condemned union shortcomings." 30 The key problem in union government, they insist, is to make union administration more imaginative, efficient and effective with more competent leadership and more longrange planning; but the democratic political process, they complain, places nearly insuperable obstacles in the way of achieving this goal.

It may well be true that the democratic process is inefficient and cumbersome; the administrative state may seem to function, at least outwardly, more smoothly and effectively. Of course, union members acting through democratic procedures will not ignore their short-range self-interest; farsighted and selfless leaders might well make more socially responsible decisions if they were free from membership restraints. Experience, however, gives scant reason to believe that if unions were less democratic they would be more efficient, produce more

25. P. 424. This ambivalence on the effectiveness of union political action reflects the attempt to demonstrate to those fearful of union political power that they have nothing to fear, and at the same time to demonstrate to the "intellectual liberals" that unions have been politically aggressive and effective.

26. P. 461.

27. Pp. 71-72.

28. Pp. $85-86$.

29. P. 90 .

30. P. 474 . 
selfless and effective leaders, or become more socially responsible. And experience has clearly demonstrated that unions, both at the local and the national level, can be sensitive to protecting democratic rights and maintaining democratic procedures and still strive for long-term social goals.

Union government obviously differs in many respects from local or state government, but all of the complaints raised by the authors against democracy in unions are in equal or even greater measure applicable to democracy in political units of government. The compelling argument for democratic procedures, whether in unions or in government, is not efficiency or effectiveness, but rather that such procedures express fundamental values, and in a society embracing those values make essential contributions which far outweigh any supposed advantages of the administrative state or enlightened authoritarianism.

The authors' impatience with and distrust of the democratic process leads them to absolve union officers almost entirely from responsibility for any of the shortcomings of unions. Union leaders are portrayed as nearly helpless before the pressures of the membership, unfairly blamed by the "liberal intellectual critics" for the selfishness and shortsightedness of their members. This belittles union leaders and depreciates their potential for shaping the attitudes of their members. Union leaders have a near monopoly on the channels of communication within the union, they have special knowledge and access to information concerning the union and its policies, and they have opportunities for extensive contacts with members and for asserting leadership. Their influence is, of course, circumscribed but they are far from helpless. Many union structures and union policies bear the imprint of leaders who not only educated their membership as to what was in the members' long-run interest but who persuaded them of their social responsibility.

Evidence presented by the authors themselves to illustrate other points demonstrates that narrow and shortsighted union policies or resistance to needed structural changes has not always been caused by membership obstruction but often by the union leader's unwillingness to abide by the democratic process. Many union leaders, the authors state, resist leadership training programs for fear that those trained will seek to compete for union office; ${ }^{31}$ educational programs are distrusted because they may lead young activists to criticize union

31. P. 185. 
policies; ${ }^{32}$ organizing new plants may be neglected because the addition of new members will add new voters in union elections. ${ }^{33}$ Many union leaders do not want to bargain for changes in work design which will eliminate monotony and increase job satisfaction because they prefer an atmosphere of discontent and opposition to whip up mili* tancy in the rank and file. ${ }^{34}$ The AFL leadership for yenrs opposed unemployment insurance, minimum wages and old age pensions for fear it would interfere with getting better contracts or cause govern. ment to compete for the loyalty of the worker. ${ }^{35}$ Union leaders may deliberately avoid grass roots political action for fear that members will insist upon a greater voice in deciding whom to endorse and what issues to push. ${ }^{36}$ The president of the Seafarers' Union accumulated a political fund of half a million dollars and supported causes not rele. vant to his members to enhance his stature and influence in the AFL, and other leaders have made large political contributions to expand their own political influence. ${ }^{37}$ In the Laborers' Union, national officers discouraged the creation of needed district councils for fear of creating political blocs that might oppose the incumbent administrntion, ${ }^{38}$ and many small unions persist simply because the leaders do not want to lose their status and influence. ${ }^{30}$ All of these instances are recounted by the authors without any recognition that union leaders must share responsibility for union weaknesses; indeed, some of these examples are used to illustrate how democracy hampers the union from becoming more efficient and responsible.

Union policies are the product of interaction between union leaders and union members, and this is true whether the union maintains democratic procedures or not. For, as the authors point out, even an authoritarian leader must in some measure be responsible to the members' desires or risk non-cooperation, loss of membership, wildcat strikes and ultimate overthrow. But the authors completely ignore the possibility that the interaction and resulting policies may be quite different if responsiveness is channeled through orderly democratic procedures. ${ }^{40}$ The need to obtain membership approval through demo-

32. P. 186.

33. P. 89.

34. P. 360 .

35. P. 389.

36. P. 403.

37. P. 404 .

38. Pp. 88, 146.

39. P. 155.

40. The authors explicitly define "democracy," not in terms of democratic rights and procedures, but in terms of "processes that keep union leaders responsive to their members." (P. 70). In describing the various processes by which members influence the 
cratic procedure impresses on the leader the need to persuade the members of the rightness of his proposals and encourages him to utilize fully his potential for shaping the attitudes of the members. This, in the long run, enables him to exercise more rather than less leadership. In addition, adherence to democratic procedures tends to develop and bring to the top those leaders who are most effective in leading by educating and persuading the members. There is, of course, no one-to-one ratio between democratic procedures and progressive or responsible leadership; our experience with democratic government forecloses such optimism. But it is our faith, not unfounded in fact, that democratic procedures produce a more enlightened electorate and more effective political leaders than alternative systems.

Recognition that democratic procedures contain significant values opens the important and difficult question of how those procedures are to be structured so that union government can best serve its multiple purposes. The authors do not even begin this inquiry; they focus only on the obstacles created by the need of union leaders to be responsive to the desires of the members. On the other hand, the longest and perhaps most interesting chapter examines the administration of unions and emphasizes the need for more efficiency, use of professional staff, program budgeting and long-range planning. The chapter is replete with recommendations but there is no discussion of how democratic procedures can best be structured to achieve these ends. There is only the decrying of how the political process interferes with good administration.

Paradoxically, the sympathetic understanding which this book attempts to bring of unions and union leaders presents a perspective which is essentially negative. The rank and file look to the union to bargain for better wages and working conditions; their concern is selfcentered and often shortsighted. Because union leaders must be elected and be representative of their members, they will respond to the pressures of their members and promote their personal ambitions. The process of selecting union officials will produce few leaders of vision and imagination, and what they can accomplish is very limited. The authors present the failures of unions and union leaders as not mere flaws, but as fundamental characteristics. This pessimistic picture

leadership, they include "calling of wildcat strikes, refusing to honor picket lines, or engaging in a wide range of activity or inactivity that will frustrate the policies of the organization." (P. 76). They include also the threat of secession, decertification, or supporting a rival union. There is no recognition that these devices are essentially those by which authoritarian regimes are resisted or overthrown and are antithetical to reliance on democratic procedures within the union. 
is largely a product of the authors' defensive posture, and particularly their efforts to discredit the criticism of "liberal intellectuals" by proving that union leaders cannot do more because they must be responsive to their members. ${ }^{41}$

What is lacking in this book is an adequate account of the actual and potential affirmative contributions of unions and union leaders, and this is the understanding which the public most needs. Racial dis. crimination by some unions is an ugly and well-known fact, but the strong measures taken by other unions to purge locals of discrimination, to induce employers to hire minorities, to reduce racial tension, and even to calm riot-torn neighborhoods-this story also needs to be told. In hundreds of cases union officers have ordered wildcat strikers back to work, have used their position of leadership to persuade members to accept technological changes which threatened job security, and have achieved ratification of disappointing contracts through democratic processes. Frequently, these things have been done in the face of organized opposition with reliance on winning majority support for responsible policies. The obstacles which union leaders face need to be understood but the achievements of union leaders in spite of these obstacles must be known for any real understanding.

Similarly, justifying unions requires more than minimizing their faults and social costs; their affirmative values must be emphasized. Perhaps the greatest contribution of unions and collective bargaining is in bringing a system of law and increased justice to the work place. The collective agreement establishes a structure of rules to replace arbitrary treatment and those rules are implemented by grievance procedures and arbitration. This system of industrial justice has developed practices and principles which are, in some respects, more flexibly fitted to the needs of individuals, and more fair and humane, than most of our other legal processes. This contribution, which is too little understood and appreciated by critics of unions, is passed over by the authors in a dozen lines. The second major contribution of unions is

41. Paradoxically, in almost every chapter the authors suggest changes in union struc. tures, practices and attitudes to help correct existing weaknesses, but those changes are commonly the very kind which they consider blocked by the unions' political process. The authors also outline the challenges which unions must meet-the need to overhaul bargaining procedures, curb union rivalries, establish sensible national priorities, develop new activities and new benefits, exercise leadership and initiative in the community, develop new leadership and attract competent professionals. But similar goals posed by other intellectuals are derided as unrealistic. In the end, pessimism prevails, for on the final pages the authors declare that "basic changes in the labor movement will depent upon the members themselves and on the society of which they are a part" and "tlic prospects for progress seem glacial." (Pp. 486-87). 
Reviews

asserting the right of workers to participate effectively in decisions which affect their working lives, a contribution which has strengthened our entire democratic process. The authors portray democratic procedures as a burden imposed by our political tradition and laws, hampering unions in achieving their purposes, but the truth may be that adherence to democratic procedures is itself an expression of one of the unions' central purposes, and the basis for their most important potential contribution. 
